\title{
On the Theme of Immortality Through Literature in Shakespeare's Sonnets
}

\section{| Min Peng | \\ School of Foreign Languages, Yunnan University, Kunming, China}

yumipeng0310@163.com

\begin{abstract}
William Shakespeare's 154 Sonnets contribute a great deal to art and literature. As a world-class master, he lives in the English Renaissance period, which is marked by a cultural flowering. Humanism is the essence of the Renaissance. It dramatically affects Shakespeare's works. In the sonnets, he reinforces his affirmation of human wisdom and knowledge of creating magnificent literature, thus bringing about the immortality of youth and beauty, which is an acute reflection of his humanistic thought of the Renaissance. This paper takes the humanism of the Renaissance as its concept. Then, this paper concentrates on investigating the theme of immortality through literature in these sonnets, including Sonnet $15,17,18,19,55,60$, and 81 . After interpreting the themes with concrete examples, this paper summarizes that Shakespeare's yearning for immortality through literature derives from his humanistic spirit. Additionally, this paper is of higher significance for valuing the principle of putting people first at the core, while pursuing a comprehensive, balanced, and sustainable development in modern society.
\end{abstract}

KEYWORDS

Shakespeare; sonnets; immortality; humanism

\section{INTRODUCTION}

William Shakespeare (baptized April 26, 1564, died April 23, 1616) is an English poet and playwright, who exerts considerable influence on art, literature, language, and the vast array of creative arts. He is also the inventor of the iambic pentameter, a form of poetry that is still widely used today. Moreover, Shakespeare's 154 sonnets catch wealthy attention from critics around the globe because they lead the public to speculate on his views on religion, sex, marriage, hence meditating on the values of love, lust, and death. The sonnets have a different set of subjects - one set chronicles the poet's desire for a married woman with a dark complexion, known as "The Dark Lady," while the other describes a conflicted or confused love for a young man, known as the "fair youth." Since the world well receives these sonnets continuously, apart from inheriting the previous thematic researches, this paper attempts to unfold the theme of immortality through literature originated from the poet's humanistic spirit, aiming to enrich Shakespeare's poetry studies and to arouse the awareness of humanism in modern society.

This paper divides into three parts. The first part is the literature review. It sums up current researches on the themes of time, love, immortality, and friendship in the sonnets. After the review of researches, a research gap in the theme of immortality through literature emerges. The second part is a brief illustration of the term "humanism." The third part is the main one, which analyzes the theme of immortality through literature in Sonnet $15,17,18,19,55,60$, and 81 , and this part is composed of three sessions. The first session 
cites verses of Sonnet 15, 17, 19 as examples, the second and the third citing Sonnet 18, and Sonnet 50, 60, 81, respectively.

Finally, this paper concludes that the theme of immortality through literature pervades Shakespeare's sonnets because the humanism of the Renaissance influences him tremendously.

\section{LITERATURE REVIEW}

Shakespeare's 154 Sonnets are widely acclaimed legacies, which attract great attention home and abroad. A host of scholars study these sonnets from perspectives of themes, images, linguistics, aesthetics, and more. Concerning the review of literature, this paper emphasizes the thematic studies of Shakespeare's sonnets explicitly.

\section{Current researches on the themes in Shakespeare's Sonnets}

Numerous scholars conduct researches on a variety of themes covering time, love, friendship, and more. Some of them mainly concentrate on the themes in a single sonnet of Shakespeare. As early as 1978, David K. Weise researches theme and structure in Shakespeare's sonnet 121. Still, in recent years, the thematic studies are not waning at all. Mesut Kuleli (2019) analyzes the structural features of sonnets 153 and 154 based on the source texts as well as six Turkish translations of these two sonnets by different translators. Moreover, Yuan Shen and Fang Liu (2016) explore the thematic uniqueness of Shakespeare's sonnets through analyzing the themes of time, beauty, and love in the cultural context of the Renaissance. However, studies of the theme of immortality through literature are not remarkably abundant. Some scholars consider that the theme of time is of paramount importance in the Renaissance period because it is a significant subject seeping through Shakespeare's sequence of sonnets. Mufeed Al-Abdullah (2020) explores Shakespeare's use of mental time travel (MTT) in his collection of sonnets, especially those addressed to his young friend from neuropsychological perspectives. Similarly, Robert Arbour (2009) also unfolds the relentless and destructive march of time in Shakespeare's sonnet 60 . Also, his study presents the importance of immortality, which echoes partially with the central idea of this paper.

As for the studies at home, plenty of scholars conduct thematic researches on Shakespeare's sonnets, among which sonnet 18 catches much closer attention. They amplify Shakespeare's humanistic idea against the absolute authority of religion and his emphasis on the wisdom of men as well as the preservation of human value through poetry (Zhou Jianxin 2008, Liu Hui 2007). Apart from thematic studies of a single sonnet, Mao Hong (2014) conducts a general thematic study, exploring the theme of anxiety in Shakespeare's sonnets. Additionally, in tune with studies abroad, myriad scholars pay heed to the theme of time in the sonnets. Shen Yuge and Li Zhengshuan (2013) discuss the theme of time in light of Wittgenstein's theory, which reflects Shakespeare's humanistic thought of the Renaissance. Other scholars also carry out similar researches on the theme of relentless and ruthless time (Chen Naochong 1992, Wu Di 2002). A little bit distinct from the above points of view, Luo Yimin (2005) analyzes the three significant motifs, that is, seizing the day, treasuring the youth, as well as reflecting on transience and mortality, buried in Shakespeare's sonnets. Unanimously, his study also serves for the end to eternity. Similar to this study, Li Zhengshuan and Wang Ming (2013) analyze the theme of eternity in Shakespeare's sonnets in terms of time, friendship, love, and life. Still, Li Zhengshuan (2002) claims that the sonnets possess a powerful internal beauty, which is adequately displayed by such themes as love, poetry, and eternity. He also adds that anxiety and jealousy are also essential factors that compose the internal beauty in the sonnets. 
Moreover, some master theses also explore the theme of love and Shakespeare's spiritual pilgrimage towards immortality under the guidance of Freudian-ism, a combination of new historic-ism and new criticism, and Platonism (Lou Liguo 2006, Liu Jing 2009). Thus, researches on the themes of time, love, and friendship are ample and abundant.

\section{Research Gap}

After the review of the literature, the author discovers that although scholars conduct extensive thematic researches on time, love, and friendship, the theme of immortality through literature undergoes limited studies. Hence, to bridge the gap, under the concept of humanism, this paper attempts to carry out a comprehensive study of the theme of immortality through literature in Shakespeare's sonnets.

\section{Humanism}

The Renaissance arises in the 14th century in Italy and lasts into the 17th century. It is marked by a humanistic revival of classical influence expressed in a flowering of the arts and literature and by the beginnings of modern science. The epoch witnesses a rapid scientific development and discovery, and much of the new understanding runs counter to the religious teaching. Instead of adhering to mysticism and faith, people turn to their own ability to reason.

Humanism is the ideological trend of the Renaissance. It is an enormous term encompassing various movements in the arts, philosophical stances, and broad applications to disciplines like psychology and education. Adopted by this paper, the term mainly refers to a philosophy that asserts the worth of the individual, the human, virtually, and the unlimited strength of humans in perfecting himself and performing wonders.

Humanists insist man's nobleness lies in his reason, and knowledge is the source of happiness, and that knowledge is the power. Against such a social and cultural backdrop, Shakespeare's works cannot avoid being influenced by the Renaissance ideology and the humanistic spirit. His sonnets are a powerful weapon to fight against the limitation of theology, appealing for the awakening of human spirit and self-consciousness.

Although the Humanist movement of the Renaissance cannot cure all ills of society, it is of the paramount importance of provoking a debate about how modern society deals with its people to achieve scientific development. Under the concept of humanism, this paper explores the theme of immortality through literature in a sequence of sonnets from the following three aspects.

\section{RESULTS AND DISCUSSION}

\section{The Theme of immortality through literature in Shakespeare's Sonnets \\ Immortality through literature in sonnet 15, 17,19}

In the group of sonnets $15,17,19$, the poet strives to immortalize his dear friend in verse, thereby saving him from the ravages of all-consuming time, which embodies Shakespeare's ardent humanistic spirit of affirming the ability of humans in the Renaissance period.

The last quatrain in Sonnet 15 "Where wasteful Time debateth with Decay, / To change your day of youth to sullied night; / And, all in war with Time for love of you, / As he takes from you, I engraft you new." means that the speaker declares war to fight against the destroyer time, for the sake of preventing his friend from changing the brightness of youth to the darkness of old age. Furthermore, more importantly, whatever time takes from his 
friend, the speaker can renew his life in his verse. Thus, the poet defeats both the ravages of time and the onset of decay because he can make youth immortal through wisdom and knowledge in creating literature. In a similar vein, apart from marriage and bearing children to inherit beauty and "live twice," according to the last two lines in Sonnet 17 "But were some child of yours alive that time, / You should live twice, -- in it, and my rhyme.", the poet amplifies that he can immortalize his dear friend in his rhyme. In order to confer immortality by verses, he highlights the power of poetry to defy time and carry the beauty of youth down to future generations. Moreover, in Sonnet 19, the last two lines "Yet, do thy worst, old Time: despite thy wrong, / My love shall in my verse ever live young." also deliver a message that despite the ravages of time, his lover shall be young forever in his poetry. The theme of Sonnet 19, as with Sonnet 15 and 17, is the defying of ravages of time to achieve immortality through literature.

To sum up, Sonnet 15, 17, and 19 all render immortality through verses and poetry. By defying time, the poet pursues immortality through literature, which is a manifesto of Shakespeare's humanism.

\section{Immortality through literature in sonnet 18}

Of Shakespeare's 154 sonnets, Sonnet 18 is probably the best known and the most widely studied. It is also one of the most straightforward in language and intent. In this sonnet, he eulogizes the power and importance of people at length, endowing them with an emancipated thought, free from the constraints of time and universe, hence attaining immortality.

Instead of encouraging the "young man" to marry and have children, he initiates to praise his beauty. The theme of this sonnet is also about preserving the young man's beauty in poems, for they enjoy an eternal presence. Shakespeare believes that while man's natural beauty withers over time, the poetry is eternal. Time can destroy beauty in summer, but the man's beauty that his sonnets portray lasts long and forever. The third quatrain "But thy eternal summer shall not fade, / Nor lose possession of that fair thou ow'st; / Nor shall Death brag thou wander'st in his shade, / When in eternal lines to time thou grow'st;" states that although everything beautiful sometimes will lose its beauty, his friend's youth shall not fade, nor will he lose beauty, for in his verse his friend will live forever. Moreover, the final couplet reiterates that as long as humankind breathes, his poetry will live on, and hence his friend's youth and beauty will be immortal.

All in all, this sonnet is a distillation of Shakespeare's progressive, humanistic spirit, which underlines humans' wisdom and knowledge of creating magnificent literature to achieve immortality.

\section{Immortality through literature in sonnet 55, 60, 81}

Sonnet 55,60 , and 81 also convey that beauty and goodness must live on in the poet's verse. That his verse can withstand and even conquer the ruthless of time exhibits Shakespeare's perception of a man-centered world and his pursuit of immortality through literature.

Sonnet 55 is one of Shakespeare's most famous works as well. In the last two lines of this sonnet "So, till the judgment that yourself arise, / You live in this, and dwell in lover's eyes," there is an intense burst of confidence as the poet claims to have the power to keep his friend's memory alive evermore. Again, this sonnet reflects the poet's paramount desire to immortalize his friend in verses. Also, in the third quatrain of Sonnet 60, time is depicted as a ravaging monster, which fades youth away, and mows down with his scythe everything that stands. In the couplet "And yet to times in hope my verse shall stand, I Praising thy worth, despite his cruel hand," the poet anticipates durability for his verse, and 
consequently for the fame of his friend. By defying the inexorable time through his verse, the poet can continue to praise the "worth" of the beloved despite the "cruel hand" of time. Moreover, in Sonnet 81, the last two lines, "You still shall live such virtue hath my pen, / Where breath most breathes, even in the mouths of men." also stress the power of the poet's "pen," alluding to his verses. In this sonnet, the poet elaborates that his verse is an enduring monument to his friend, whose praises live in the mouths of unborn generations, even though he must die, and people may forget his friend's personality.

Hence, the pursuit of immortality through literature is a prominent theme in the group of sonnets. Youth and goodness are eternal, just like art and literature, which manifests the dignity of human beings crucially.

\section{CONCLUSION}

The Renaissance spirit remarkably influences Shakespeare because the necessary tune of his sonnets is humanism. He extols human dignity, value, and creativity in his sonnets far and wide.

By challenging the devouring time, he eulogizes the dignity and immortality of human beings through literature, which is a dramatic portrayal of his humanistic spirit. Free from the constraints of time, he also conveys that man is the center of the universe, and man has not only the right to enjoy the beauty of the present life but the ability to create splendid literature. The theme of immortality through literature penetrates Shakespeare's sonnets. It gives expression to his brave fight for the right of men and against religion and mythology.

Besides, in the process of modernization, this paper is of the vital importance in building a harmonious society, where people's ability is brought into full play, thus achieving comprehensive, balanced, and sustainable development.

However, this study also bears some limitations. It does not take into account Shakespeare's obsession with immortality through images, offspring, and love. It only involves the theme of immortality through literature (verses, sonnets, and poems) in order to underscore that art and literature can transcend time and universe to enlighten people in the world about their ability to think and to make rational determinations. Researchers can include these points in their future study of Shakespeare's sonnets.

\section{ACKNOWLEDGMENTS}

I would like to express my heartfelt gratitude to my supervisor Ms. Xu Zhiying for her encouragement and enlightenment throughout this study. Her sense of responsibility and patience impresses me the most. I am also indebted to my parents, who have never failed in their support in my graduate study.

\section{REFERENCES}

Arbour, R. (2009). Shakespeare's Sonnet 60, The Explicator, 67:3, 157-160, DOI: 10.3200/EXPL.67.3.157-160

Chen, N.C. (1992). On the Theme of Time in Shakespeare's Sonnets. Journal of Foreign Studies, 4, 47-50.

Kuleli, M. (2019). Structural and thematic analysis of Shakespeare's sonnets 153 and 154 with their Turkish translations. RumeliDE Dilve Edebiyat Araştırmaları Dergisi, (15), 353-376. DOI: 10.29000/rumelide.580643

Li, Z.S., Wang, M. (2013). A Study of the Theme of Eternity in Shakespeare's Sonnets. Hebei Academic Journal, 33, 108-111.

Li, Z.S. (2002). On the Internal Beauty in Shakespeare's Sonnets. Foreign Languages and Their Teaching, 7, 53-56. 
Luo, Y.M. (2005). The Three Major Motifs in Shakespeare' s Sonnets. Journal of Southwest China Normal University (Humanities and Social Sciences Edition), 2, 154159.

Liu, H. (2007). Contending with Time Through Literature -- On Shakespeare's Sonnet 18. Movie Review, 9, 97.

Liu, J. (2009). Spiritual Pilgrimage Towards Immortality in Shakespeare's The Sonnets. M.A. Thesis, Changsha: Central South University.

Lou, L.G. (2006). On the Theme of Love in Shakespeare's Sonnets. M.A. Thesis, Shanghai: East China Normal University.

Mufeed, A. A. (2020). Mental Time Travel in Shakespeare's Sonnets: Aesthetic Art in Neuropsychological Perspectives. English Language and Literature Studies; Vol. 10, No. 1.

Mao, H. (2014). On the Theme of Anxiety in Shakespeare's Sonnets. Literary and Artistic Contention, 6, 172-175.

Shakespeare, W. (1916). Sonnets, from the quarto of 1609, with variorum readings and commentary. Ed. Raymond MacDonald Alden. Boston: Houghton Mifflin.

Shen, Y., Liu, F. (2016). A Thematic Study of Shakespeare's Sonnets. English Language and Literature Studies, 6, 102.

Shen, Y.G., Li, Z.S. (2013). To Say What is 'Not to Say' - An analysis of the Theme of Time in Shakespeare's Sonnets. Journal of Hebei University (Philosophy and Social Science), 38, 134-138.

Weiser, K. D. (1978). Theme and Structure in Shakespeare's Sonnet 121.

Studies in Philology, Vol. 75, No. 2, pp. 142-162.

$\mathrm{Wu}$, D. (2002). On the Theme of Time in Shakespeare's Sonnets. Foreign Literature Review, 3, 88-93.

Zhou, J.X. (2008). An Analysis of Themes in Shakespeare's Sonnet 18. Movie Literature, 4, 99.

https://www.williamshakespeare.net

http://www.shakespeare-online.com

https://www.wisegeek.com/what-is-humanism.htm

www.merriam-webster.com

Www.poetryfounfation.org 